\title{
LANDSCAPE PATTERN VERSUS FARMING DEVELOPMENT. THE CASE OF THE POST-MARL HOLLOWS (PMH) LANDSCAPE IN POLAND
}

\author{
Iwona MARKUSZEWSKA \\ Adam Mickiewicz University, Poznań, Faculty of Geographical and Geological Studies, POLAND \\ iwmark@amu.edu.pl \\ DOI: http://doi.org/10.23740/TID120171
}

\section{ABSTRACT}

This article discusses the presence of unique landscape elements (post-marl hollows) in an intensively operated farming region. The selected case study (the environs of Krotoszyn in the Wielkopolska region, Poland) represents an example of a human-designed landscape in which post-marl hollows (PMH) were created as a consequence of the soil-marling process. PMH are vital ecological habitats which have an influence on the high quality of the rural landscape. Currently, as PMH are undergoing the vanishing process, it seems essential to find a solution to maintain these unique landscape elements.

The main aim of this paper is to analyse human-nature relationships during the current changes taking place in the agricultural landscape in order to get the answer to the question: how is this affecting the PMH? The study evaluates farmers' pro-environmental behaviour and defines their identity with the local landscape that has been beneficial in predicting the forthcoming shaping of the landscape. The data describing the PMH were collected in the years 19982016, while conducting cartographic analysis, a literature review and repetitive field research. Additionally, remote sensing and geoportal database were used to analyse the PMH changes. Also, interviews and discussions with farmers and representatives of the local administrative body were conducted.

Results indicated that local rural communities are little concerned about the environment, particularly when it pertains to the issue of conservation of the local landscape heritage (i.e. PMH). In addition, the lack of support from the administrative body makes more difficult the opportunity to maintain a unique landscape pattern, as described in this paper.

Keywords: post-marl hollows (PMH), agricultural landscape, landscape pattern, human-nature relationships, pro-environmental behaviour, place attachment

\section{INTRODUCTION}

The concept of landscape, when considering it from the point of view of landscape ecology, is defined as a complex system, in which both natural and cultural factors influence one another and change over time. The approach to landscape research has focused on the landscape pattern, i.e. the spatial arrangement of landscape elements (marginal habitats and corridors), as well as on the interactions between them (Forman \& Gordon, 1986). In other words, the connections between landscape characteristics play a crucial role in an intensively used area, such as an agricultural landscape. The non-productive landscape components that contribute to this landscape connectivity are, inter alia, hedgerows, middle-field balks, wood-lines, drainage canals, and ditches. Maintaining this connection is relevant to many threatened animal species living in the agroecosystem, where ecological corridors ensure shelter and enable movement. The efficiency of the landscape connection depends on the width and length of the corridors - 
condition of the vegetation structure - degree of corridor fragmentation, and distance between the isolated landscape islands they link with. Nevertheless, the corridors do not always have to be linearly shaped. Depending on the landscape context, also extensively used areas and small patches located side-by-side (the so-called 'stepping stones') can support movement (Markuszewska, 2006). In spite of this, ecological corridors and fringe elements fulfil aesthetic, social and economic functions by delivering different kinds of goods that are included into the concept of ecosystem services (de Groot, 2006). In addition, the grid of corridors and environmental patches creates a specific landscape pattern which is irreplaceable in preserving biodiversity. Particularly in open and semi-open rural landscapes, ecological corridors increase the landscape mosaic and improve landscape attractiveness (Pinto-Correia, 2008).

The agricultural landscape has an influence on the daily life of the landscape users, as they live and work in that specific place. On the other hand, rural dwellers actively shape the landscape to adjust the space to their needs. Throughout the centuries, different manners of farmland cultivation, space planning and landscape management have created distinct rural landscapes. Because of the fact that farming systems were regionally diversified (necessary to adapt to diverse natural conditions and local traditions in farming), we can now see the great diversity in landscape mosaics throughout European countries (Vos \& Meekes, 1999; Markuszewska, 2013). However, remnants of the old landscape are threatened, and among the different reasons responsible for this is mainly the cultivation technology that is currently being used. Mechanisation requires a simple landscape pattern, i.e. a kind of open landscape that would be more useful for tillage. Some researchers, e.g. Walker and Ryan (2008), emphasised that changes to the landscape, as described above, were not indifferent to the local inhabitants, in whom a sense of loss is observed. This shows strong emotional attachment to the landscape heritage and patrimony; therefore, in order to conduct reasonable management of rural areas, gathering data on the connections that link the local society with that society's place of living seems to be essential. Furthermore, this information can be helpful in the process of protecting a unique landscape pattern. The need to preserve and respect local landscape values is becoming increasingly more necessary, and obviously, the involvement of local actors is essential to provide successful solutions. Marcucci (2000) pointed out that old rural landscapes are valuable due to cultural aspects, where the history of the place and the local tradition are most precious; however, the history of a place not only links the past and present, but is also essential when making decisions regarding future changes of the landscape.

Consequently, an emotional connection between the locals and the landscapes is vital in creating a good basis for maintaining the remnants of the old landscape (Zimmerbauer \& Paasi, 2013). Here the locals' memory plays a special role that builds a spiritual link of emotional attachment to the place of living. Wheeler (2014) explains that memory, as an informal aspect of history, persists in the rural landscape and is linked with rural dwellers' everyday lives.

It is said that farmers from the post-socialist bloc are more emotionally devoted to the land, as the historical circumstances and attachment to the land make them more sensitive and engaged in protecting the family heritage (van Dijk, 2007). This linkage is strengthened over time due to the fact that they spend their whole lives in one specific place, cherishing the patrimony. Conversely, attachment to a place builds emotional and psychological connections between people and their place of living (Walker \& Ryan, 2008). Thus, it is expected that people with a high sense of place attachment should be more involved in the protection of the local environment (Anton \& Lawrence, 2014). 


\section{METHODOLOGY}

The main aim of this paper was to analyse human-nature relationships in the context of current changes taking place in the agricultural landscape that have an impact on post-marl hollows (PMH). The study evaluates farmers' pro-environment behaviour and defines their identity with the local landscape that has been beneficial in predicting the forthcoming shaping of the landscape.

The paper also contributes to existing data on the protection of the traditional pattern of a rural landscape. The research I conducted was in a region that stands out in terms of uniqueness of the traditional Polish agricultural landscape: the landscape of PMH in the environs of Krotoszyn in the Wielkopolska region (Figure 1). What is important here is the fact that the selected landscape represents the highest achievement of culture values and plays a significant role in shaping the social identity (Markuszewska, 2006). However, at the same time, this region is one of the most important farming production areas, which is essential in assessing the landscape changes.

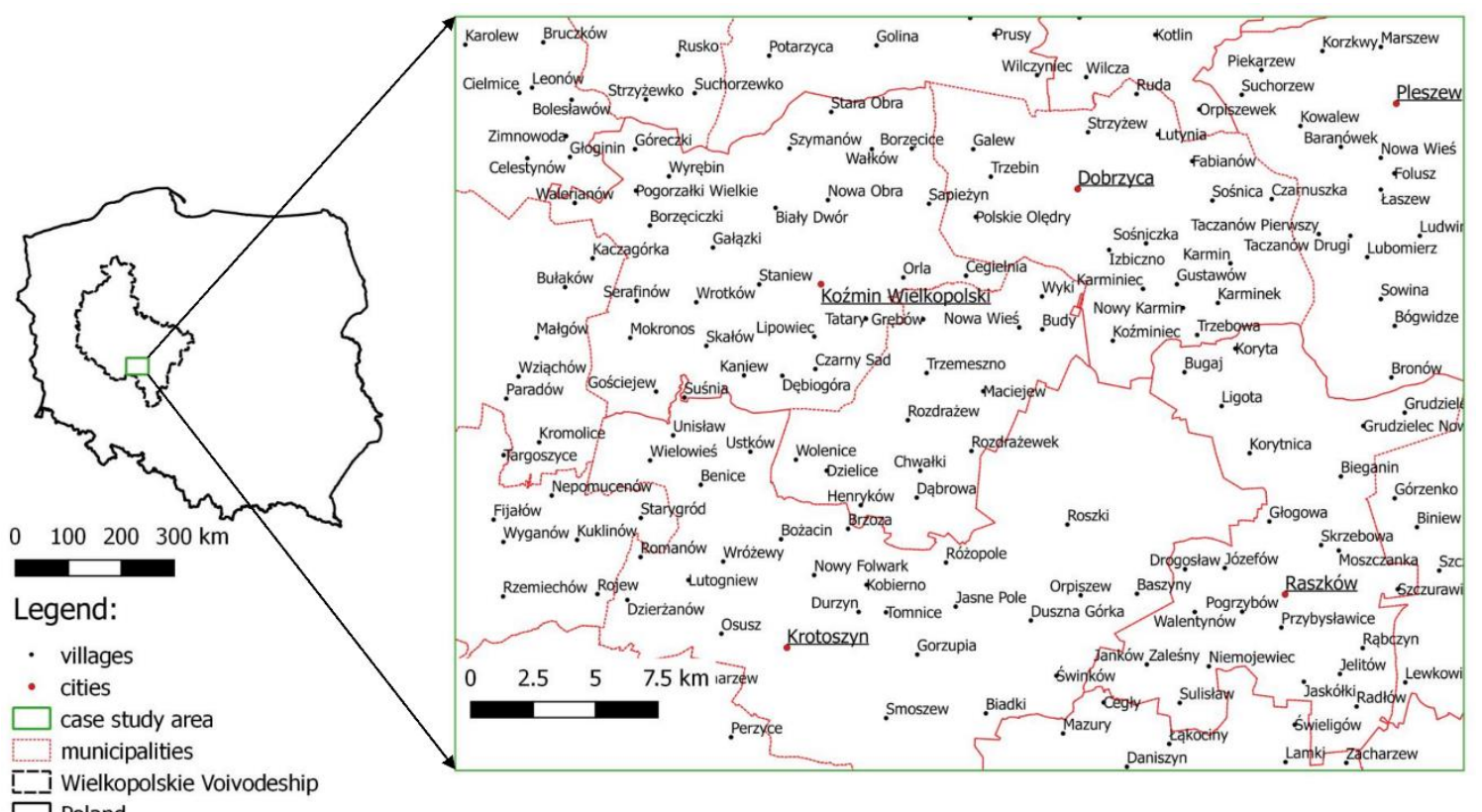

Figure 1: Location of the case study

Source: Compiled on the basis of Państwowy Rejster Granic and Państwowy Rejestr Nazw Geograficznych

In this paper, different approaches to landscape research are presented, which include comprehensively the environmental, economic, and social aspects of landscape changes. The study was conducted in a qualitative and quantitative manner within the research framework.

The quantitative data describing the PMH were collected between 1998 and 2016, while conducting cartographic analysis, a literature review, and repetitive field research. To estimate changes in the number of $\mathrm{PMH}$, the following cartographic materials were used: Messtichblätters from the years 1887-1890, photomaps from 1941, topographic maps from the 1990s, and aerial photos from the 1990s. The current stage was interpreted using geoportal database (geoportal.gov.pl) that was verified by reconnaissance field study lined with landscape photography performance. In addition, the characteristics of PMH (size, shape, depth, flora 
diversification) was recorded in the field. In 1998, some pre-fieldwork was made in order to recognise the situation. A specific field research was done between 1999 and 2004, in different seasons of the year. Additionally, monitoring observation was conducted in 2015 and 2016.

To evaluate farmers' pro-environmental behaviour and define their identity with the local landscape, interviews and discussions were carried out in July and August 2016. Each interview was anonymous, semi-structured, and consisted of several questions. The interviewers were asked about their attitude to landscape, their knowledge about PMH and the history of the local landscape, their plans for future landscape changes. However, because the survey was semistructured, several spontaneous questions were asked during the conversation. Several of these statements are quoted in the following sections; however, all interviews remain anonymous. Additionally, a short telephone conversation was conducted with representatives of the local administrative body. They were asked about their role as advisers and supporters in farmers' decision about shaping the landscape in the scope of PMH protection. In the end, 27 interviews with farmers and 3 with officials were collected.

\section{RESULTS AND DISCUSSION}

\section{History written into the landscape}

The process of soil melioration, called 'soil marling' or 'soil liming', is connected with the origin of PMH. This manner of fertilising the soil uses marl for de-acidification and amelioration of the ground's physiochemical properties. In effect, an increase in colloid content and improvement of sorption are achieved. This type of soil improvement has been known since ancient time, however, only in the $19^{\text {th }}$ century, did it become widespread thanks to the work of Mathieu de Dombasle, a French agronomist and pioneer in farming progress. As Stankowski (2012) pointed out, in the upper layer of the clay soil profile, which is affected by erosion and decalcification, a lower amount of calcium carbonate is observed; whereas, below this level, a heavy concentration of carbonate can be found, where calcium carbonate appears in large accumulated spots, i.e. the so-called 'marl'. Because of its property, marl is used for soil deacidification (Niegoszisz, 1993).

At the beginning of the $19^{\text {th }}$ century, in the Wielkopolska region (a part of this area comprised the case study), soil melioration was widely known and practised (Dembiński, 1954). Marling, as a way of soil improvement, had initially been implemented there by the Prussians, who occupied this part of Poland in the years 1875-1918. As a result the Prussian government establishing the Colonisation Committee, until 1918, ca. 21 thousand Prussian families settled in the Wielkopolska region, i.e. via purchasing land (Szoszkiewicz, 2000). Admittedly, this massive settlement changed the cultivation technique and advanced mechanisation of farming was possible to implement, which set the Wielkopolska region apart, in the same position as other regions of Western Europe.

The archive literature provides several other examples of regions in Germany, e.g., in Brandenburg and Mecklenburg (Behm, 1993), where these kinds of marl pits existed, and, a great part of them have survived to the present day. As Woldsteadt mentioned (1929), the aim of marling was to enrich barren and acidified sand soil, by using boulder clay. Soil improved in this manner constituted the basis mainly for the cultivation of sugar beet, rape, and wheat (Geinitz, 1920). Additionally, Gripp (1924) emphasised the massive nature of marl exploitation, which was linked with a market-oriented explanation. 
The analysed cartographic data and conducted field surveys show that the second part of the $19^{\text {th }}$ century is assumed to be the beginning of marl exploitation in the Wielkopolska Region, although, the activity was suspended in the 1950s, when marl was replaced with lime because it was a more easily available product and a cheaper way of fertilising soil. It is worth noting that the environs of Krotoszyn are the only area in Poland where the remnants of PMH can be found. However, this also means that marl exploitation in the Wielkopolska region was exclusively conducted on this land in the past.

According to the study results, marl was unearthed from a depth of 4-5 metres. The bottoms of hollows had the highest accumulation of calcium. Hollows created in this manner were filled with ground water and transformed into water tanks, whereas the excavated material was scattered on the ground. The rim of the hollows, which was a small strip of uncultivated ground, was vegetated and, over time, created a diversified composition of plant species.

The spatial arrangement of the PMH was intentionally designed and mostly depended on the size and shape of the fields. Most of the hollows create linear forms, located as a chain or several chains of hollows parallel to one another and placed more or less within the same distance. The choice of this type of pattern was connected with small-sized fields, and caves were situated close to the middle-field paths to save the cultivated land. In addition, there was another chaotic way of obtaining a PMH pattern - with disorderly spread pits which more often accompanied large-sized fields. The motive for this spatial arrangement of PMH was a reasonable distribution of hollows that should be able to deliver marl to each part of the field. The different types of PMH arrangements are presented in the Figures 2-4, where occurrence of $\mathrm{PMH}$ was marked in red colour.

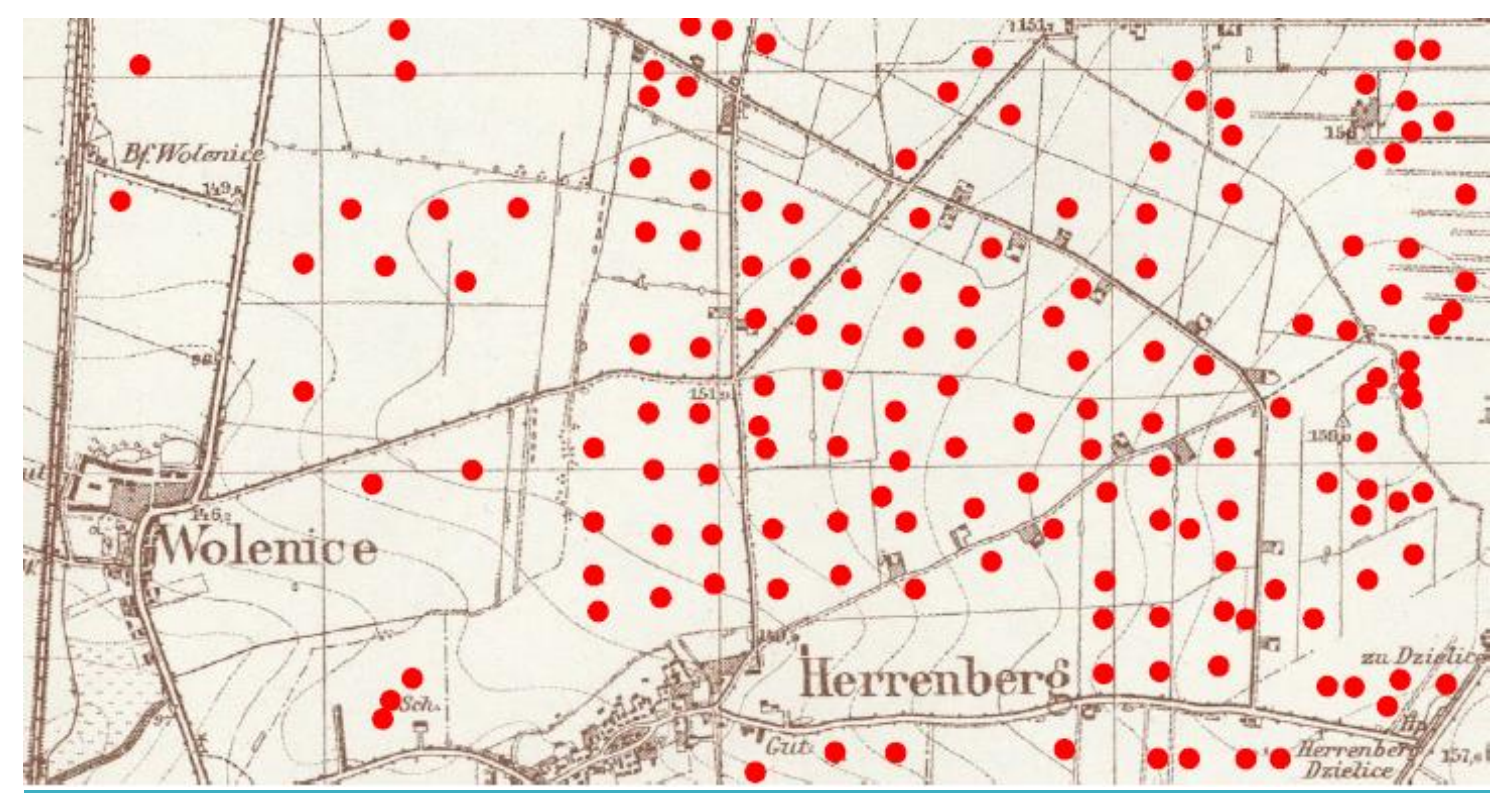

Figure 2: Distribution of PMH in large-sized fields - an example from the surroundings of Dzielice (Herrenberg) village (PMH are marked in red) 


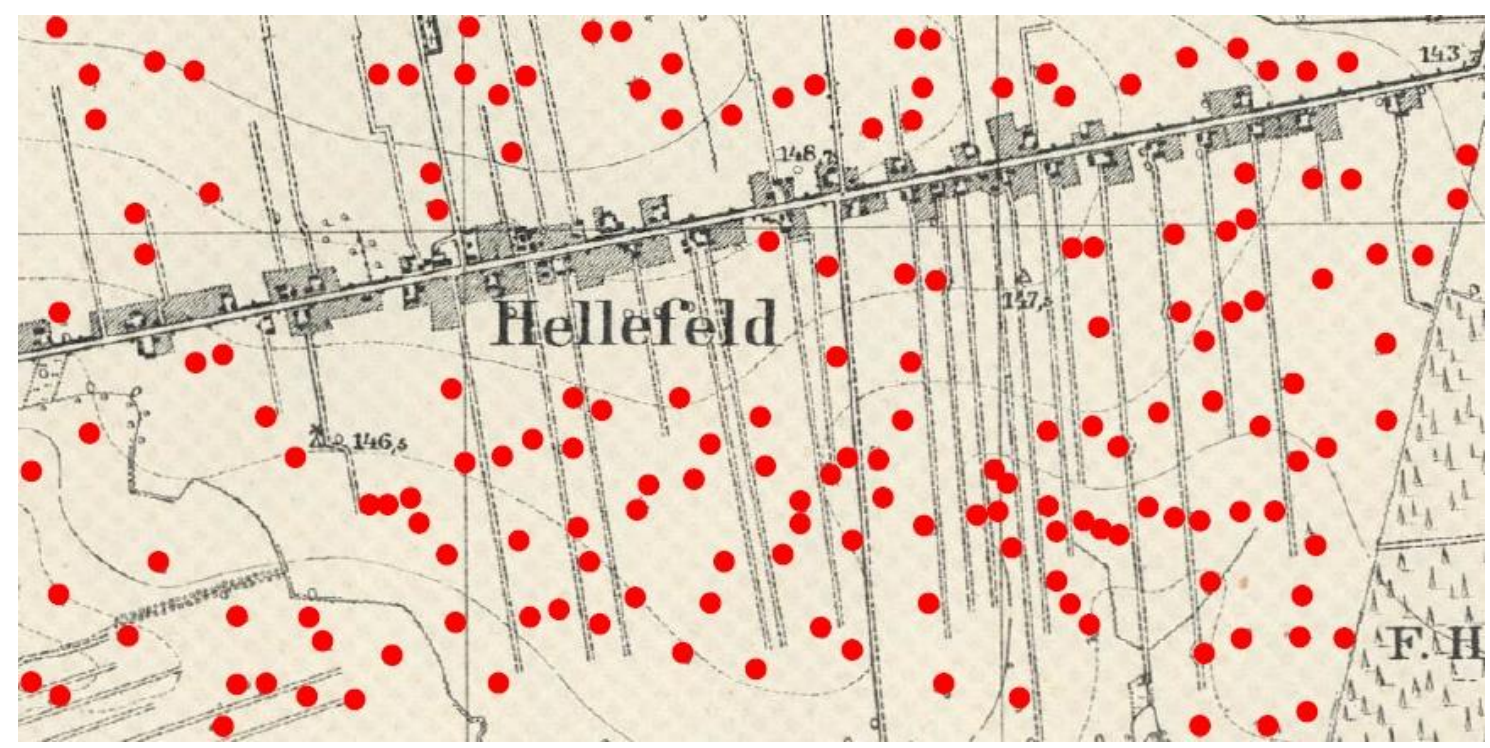

Figure 3: Distribution of PMH in small-sized and long-strip fields - an example from the surroundings of Jasne Pole (Hellenfeld) village (PMH are marked in red)

Source: Messtichblatt, 4271 Rozdrazewo, from 1887, scale 1:25,000, Archiwum Map Zachodniej Polski

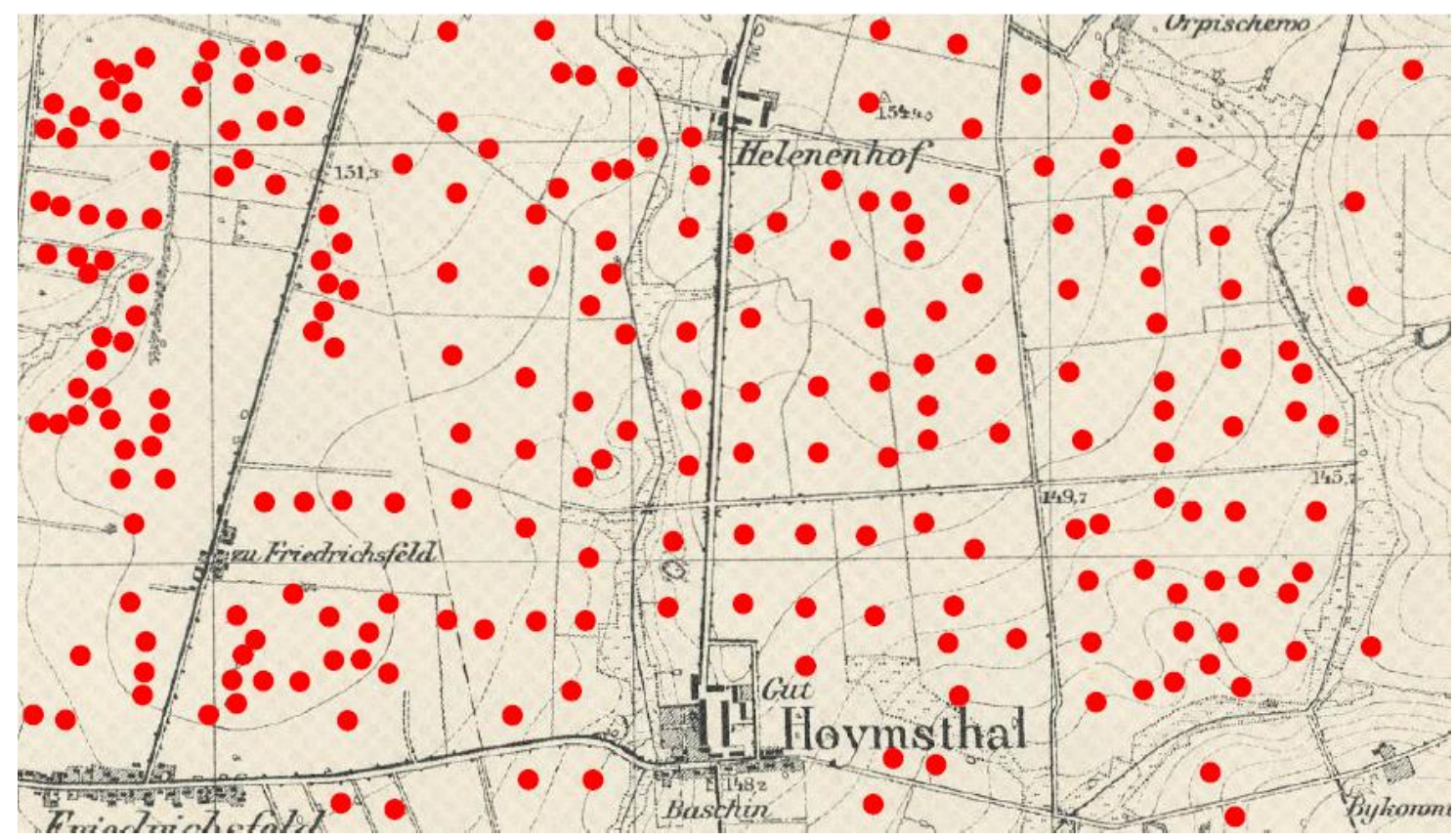

Figure 4: Distribution of PMH - an example from the surroundings of Baszyny (Hoymsthal) village (PMH are marked in red)

Source: Messtichblatt, 4271 Rozdrazewo, from 1887, scale 1:25,000, Archiwum Map Zachodniej Polski

Messtichblatt's analysis revealed that, at the end of the $20^{\text {th }}$ century, the maximum range of marl excavation covered an area of 30 square kilometres. Today, $\mathrm{PMH}$ can be found on less than one half of this initial spatial extent. Correspondingly, the number of hollows decreased systematically (Table 1 ). 
Table 1: A decreasing trend in the number of $\mathrm{PMH}$

Source: Compiled by the author

\begin{tabular}{|l|l|}
\hline Period & Number of PMH \\
\hline 1880 s & ca. 14,500 \\
\hline 1940 s & ca. 8,000 \\
\hline 1990 s & ca. 2,700 \\
\hline 2016 & ca. 800 \\
\hline
\end{tabular}

Natural processes (e.g. deposit sedimentation) and human activities (e.g. farmland drainage, backfilling) influenced and led to this transformation. Melioration undoubtedly contributed to the drying of water ponds, which explains the decreasing number of $\mathrm{PMH}$, because water-free hollows were easier to fill with waste and other materials. Subsequently, progressive shallowing of the hollows allowed to include them into the cultivated area.
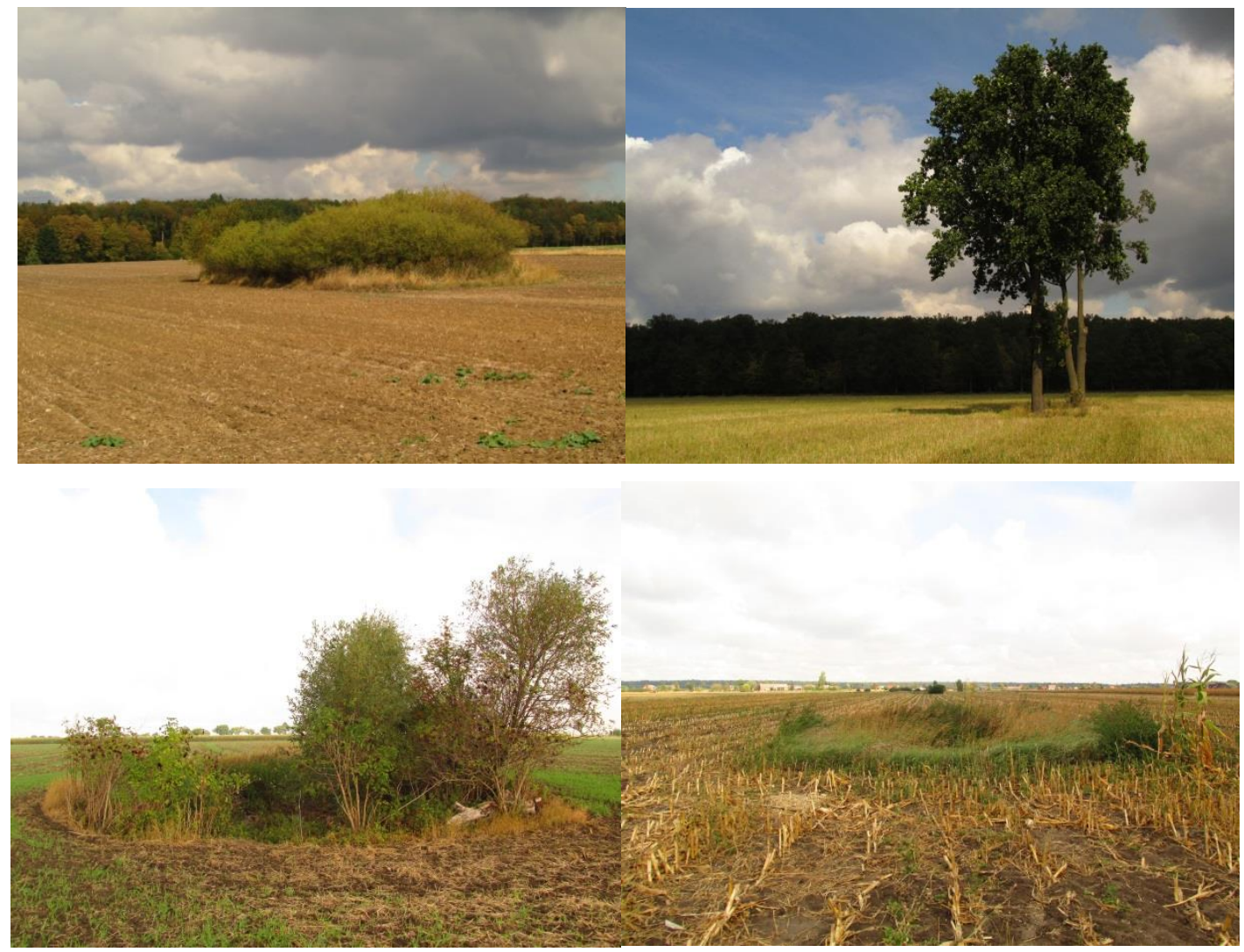

Figures 5-8: Examples of PMH presenting an advanced stage of alteration Source: Iwona Markuszewska, 2015

The first study regarding the measurable characteristics of $\mathrm{PMH}$ was conducted in the mid- $20^{\text {th }}$ century (Bartkowski, 1949). At that time, the hollows were of impressive size; three categories of $\mathrm{PMH}$, according to their shape, can be distinguished: (1) the length of the longer sides diverges 20-30 metres and of the shorter ones 7-15 metres, (2) the length of the longer sides varies between 80 and 100 metres and of shorter sides -3 and 6 metres, and (3) both lengths equally vary between 60 and 80 metres. The first two types are connected with rectangular, small-sized fields, whereas the last type pertains to square large-sized fields. Similar changes may be 
observed for the depth of the hollows, which oscillated, in the mid-century, between 1.5 and 4 metres, while currently the maximum depth is 1.5-2 metres.

The results of field research, which was conducted over the past two decades, proved that the landscape underwent ongoing simplification: from 14,500 objects to currently 800 . However, a large number of these manifest an advanced stage of alteration (Figures 5-8). There is a group of PMH without a clearly defined depth (ca. 100), but still with poor vegetation. Another category represents objects (ca. 200), which are shallow and fully overgrown with plants; another unusual form, indicating a progressive transformation, are single trees or shrubs left in the fields in places where the hollows were located. Water ponds are also steadily being dried. The hydrological condition in the hollows differs annually; however, over the last few years drought has become an increasingly severe issue.

\section{Between landscape beauty and landscape usefulness}

The research region stands out from the neighbouring areas by its relatively high share of familyfarms. A family-farm is a type of farms that is managed by the owner and his/her family, where the land is handed down from generation to generation (Act on Shaping the Agricultural System, 2015). The farmers interviewed for this study spent their whole lives farming. Only in several cases had they been forced to do so for family reasons, but this was mostly a deliberate choice enhanced by the prestige of inheriting land property. Yet, irrespective of the succession roots, farmland is the fundamental basis for these farmland owners to be able to boost their economic income.

The aim of the study (via conversations with farmland owners) was to gather the locals' opinions regarding the non-material value of the farmland as a symbolic module cementing former and later generations which creates a deep sense of cultural identity and belonging to one's place of birth. It was assumed that strong emotional attachment to patrimony defines one's relation to farmland; thus, it was expected that the farmers would unwittingly take care of the landscape and avoid implementing activities that would be in conflict with and infringe 'laws of nature'.

The results of the study revealed that the farmers' interest is generally economically oriented. Their unwillingness to maintain a specific landscape pattern is very often supported by practical aspects, as one of the farmers, aged ca. 50, from Różopole village, confirmed: Because the hollows are quite large they don't bother me when I work in the field. Besides, I've gotten used to them, so I don't see why I should destroy them. Most of the surveyed farmers confirmed this statement (89\%). However, the level of importance of material benefits was quite surprising, as the rural dwellers affirmed that the PMH are like 'natural' landscape components and that they appreciate these small landscape elements which affect one's feeling of landscape beauty. The way in which they described the origins of the $\mathrm{PMH}$ was emotionally marked. In many interviewees' memories, images from the past are still alive, as one of the women from Jasne Pole, aged ca. 70, explained: The hollows were dug deep, at a depth of 4-5 metres. It was a very hard job because everything was done manually. But it was also dangerous. Many people lost their lives, for example my grandfather was crushed by a heap of slippery soil... The dugout clay was excavated to the surface and left near the hole for some time. After drying it was scattered in the fields.

It is interesting to note that from the onset, $\mathrm{PMH}$ caught interest as an 'ecological' source of supplying a useful and practical 'service'. In other words, peasants made use of the hollows and their serviceableness was mentioned by many of them, e.g., one of the interviewed residents of Roszki village, aged ca. 40, explained: Still in the 1950s and 1960s you could find here large water ponds, the favourite habitats of waterfowl. At that time, hunting was very popular and duck hunting was an exceptional attraction. After that, someone drained the water ponds, which 
reduced the number of birds... Also game hunting was organised for: deer, roe deer, hares, which in the past we had been able to find in a larger number than now. Anyway, these wells are their living space, even today ... but the fewer holes, the fewer animals.

Another practical benefit is timber harvesting. Temporarily undercut trees and shrubs are used for fuel in households. Among the tree species growing around the pits are Salix viminalis and Salix purpurea, which are widely used. Particularly in the past, the shoots were used to plait wicker baskets, make brooms and other items of everyday use. Furthermore, until today, some of the water ponds, and particularly the deep ones, are constantly filled with water and are used as fishponds not only by the farmers for their own needs, but also by other rural residents as well.

In addition, another way the $\mathrm{PMH}$ are used should be mentioned here: namely, the $\mathrm{PMH}$ are spots where waste is deposited, even if this 'practical' use is far from being environmentally friendly. Fortunately, ever since the appropriate provisions of the Act on Wastes have been implemented: Illegal waste depositing is no longer profitable. From time to time the water ponds are controlled by personnel of water management companies and when they find polluted reservoirs, the farmer of the fields on which the pond is located is financially penalised explained one of the farmers from Orpiszew village. Consequently, pollution is not much of an issue anymore, because of this legal regulation. Nonetheless, in the past, when the law was more permissive, different kinds of waste, including left-overs of pesticides and artificial fertilisers, were quite commonly found there.

Finally, the inestimable role of PMH as stepping stones should be stated here. The distinct spatial distribution and spatial arrangement of $\mathrm{PMH}$ creates linear chains that are invaluable in moving game animals in the agrarian production space. It can be seen in the Figure 9, where PMH are located in the field adjacent to the forest. The field observation conducted here proved this and the role of PMH as sheltering places, which increase the animals' sense of security.

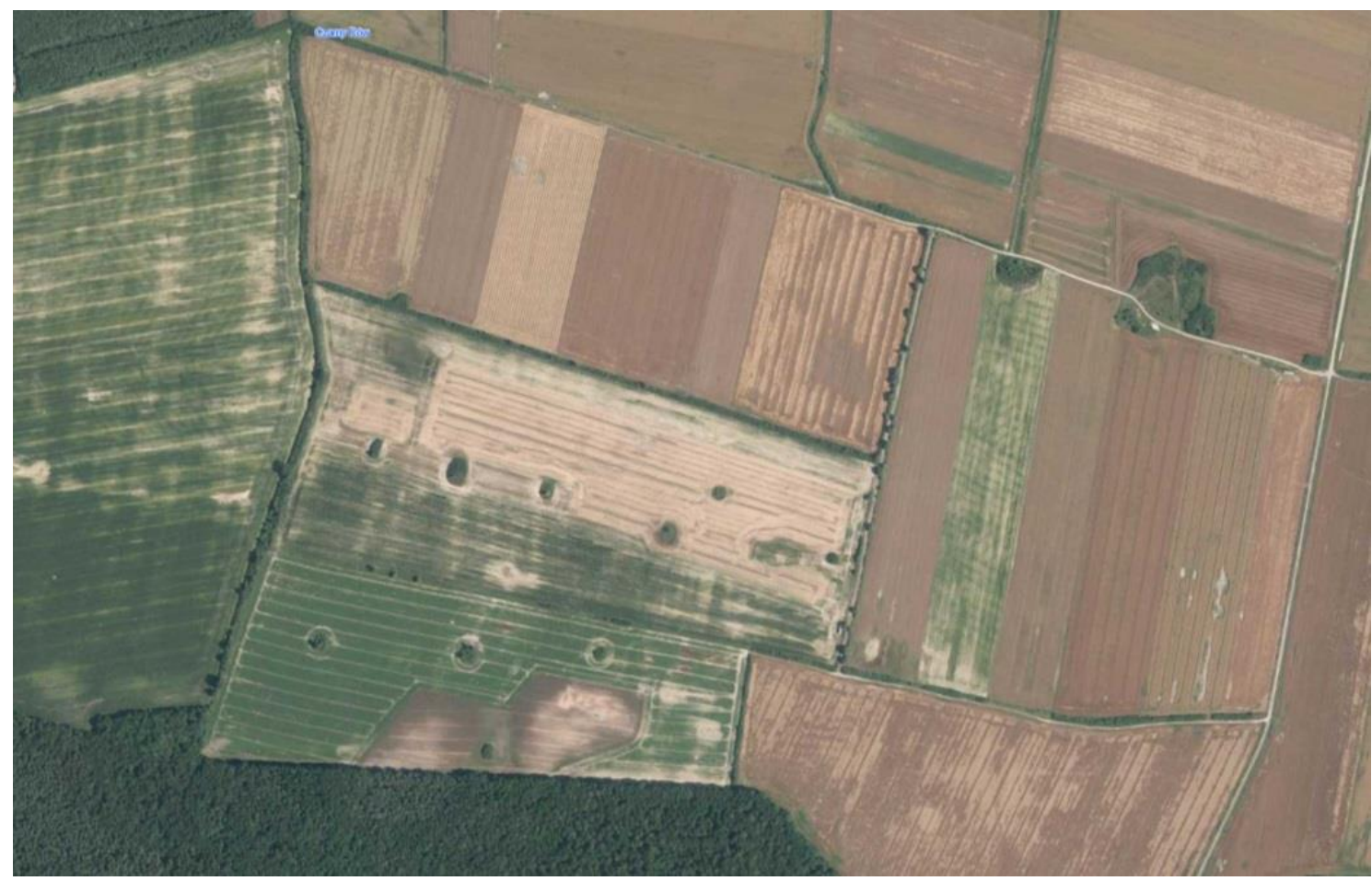

Figure 9: PMH as stepping stones - an example from the surroundings of Potarzyca village 


\section{The parents' landscape - the children's landscape: on the future of PMH}

As was stated above, in recent decades, PMH have significantly decreased in number, size and the territory on which they can be found. Thus, when it comes to the future of $\mathrm{PMH}$, it seems that whole landscape simplification is a matter of time.

Until quite recently, the reasons for maintaining PMH were because the size of the field could support the existence of these peculiar landscape elements. Analyses of images and field observation proved the hypothesis that the larger the field, the bigger the number of hollows was. This way, several areas, i.e. enclaves, with a particularly good ecological condition of the PMH were detected (Markuszewska, 2006). Nonetheless, over the past several years, it was fairly surprising to observe a relatively large number of $\mathrm{PMH}$, with good water and flora conditions, disappeared. On the other hand, tiny pits or their remnants (a single tree or bush) can still be found regardless of the field size. When asked about the reasons of keeping them, the farmers or owners of the farmland, replied: The hollows have always been present, why should this be changed?

In addition, when searching for the reasons for maintaining the $\mathrm{PMH}$, it was expected that having information about the landscape history would support the idea of protecting the local landscape heritage. In other words, the farmers' emotional awareness regarding the uniqueness of PMH would influence, at least to a small extent, reasonable landscape shaping, which basically means the protection of $\mathrm{PMH}$. Nevertheless, the study provided quite a contrary conclusion, with only one exception, namely a farmer from Bugaj village, aged ca. 40, who was a collector of Messtischblatt map sheets, dating back to the beginning of the $19^{\text {th }}$ century. During the conversation, he drew my attention to the decreasing number of cavities in the region where he lived and emphasised the negative consequences this had on the environment and future development of the landscape. Also, he had a critical opinion about the permanent backfilling of hollows that was commonly being practised by his neighbours. Yet, if the holes were being backfilled, this meant that the PMH must have been of only little interest and little emotional value to most of the landscape users living in the studied region.

It is interesting to note that it is not the age of the landowners, but that the 'practical issue' is the main motive of PMH removal, as an equal number of both supporters and opponents (a slightly more than $96 \%$ in total) was found in the older and younger generations alike, e.g. in the past, this 'practical issue' decided about the selection of $\mathrm{PMH}$, and the most hindering ones were removed, thus only those of them which hadn't been destroyed by our parents are still preserved - commented one farmer, aged ca. 60, from Różopole village. Another farmer, aged 40, claimed: I have only little awareness about the hollows and for me they are just something that makes tillage cumbersome. Soon I will take over the farm from my father and what I am going to do is to modernise it, so perhaps I will get rid of them'. A farmer from Biadki village, aged of 40, added: They're nice, but I have to admit that I've just gotten rid of one of them and I am going to do the same with the other. They have been here for a long time, but in the end my neighbour got rid of his hollows in his field and I will do so likewise. Finally, an interviewer aged 50, from Orpiszew village, confirmed: Some time ago I dried my hollows and now I am putting stones collected from the fields there. So now they are at least practical.

With the above findings taken into consideration, the last step of the research was to find out if the PMH can shape the agricultural landscape in the future. So, the interviewed farmers were asked whether they would agree to protect the PMH. They were informed that some types of treatments would be prohibited as an obvious consequence of $\mathrm{PMH}$ protection, e.g., backfilling, 
drying and removing vegetation, which are now the most common farming actions, would not be possible according to the new legal provisions. The farmers were very reluctant to accept this idea as well as any hypothetical proposal to introduce changes. They claimed that this restriction went against their rights to take decisions regarding the future of their land property. The strongest opponents argued: But this is my field and the decision is mine, isn't it? (a farmer, aged 45 , from the village of Janków Zaleśny). In fact, there was no one who would have liked the idea of PMH protection.

On the other hand, it is not easy to take an unambiguous decision when some voices of reflection are heard: In my opinion it is very unfair. I still have hollows in my fields and maybe soon, if they become protected, I will have a big problem. The other farmers who have no hollows have no worries. Besides, there are fewer and fewer hollows and before this law comes to existence, farmers will remove them completely from the space (a farmer, aged 53, from Świeligów village); or another reply: It's a difficult question. It is expected from me, as a farmer, to deliver products, food, because this is my role and I'm paid for this, I mean, my income come from this work. But no one cares that the hollows bother me during work in the field. What's more, it is expected of me to protect the landscape. I know that the hollows are nice, but I have to decide what is more important for me. Also because I am the owner of this land... I know, there are some compensatory payments to maintain extensive land use (direct payment), but it is rather not my area of interest. I'm focused on intensive production.

On the other hand, representatives of the local authorities responsible for landscape protection (Department of Municipal Economy, Environmental Protection and Agriculture in the local commune in Krotoszyn) claimed that it is exclusively the farmer's decision if he/she is willing to protect the $\mathrm{PMH}$, with the manner of protection following the legal rules of the Ustawa o ochronie przyrody (Act on Nature Protection, 2004). However, quite recently, another option for the protection of non-productive elements of the agricultural landscape was offered to farmers. This concerns pro-ecological areas designed in the context of promoting 'green farming', i.e., for maintaining the $\mathrm{PMH}$, the farmers would be financially supported (compensatory payments). At this moment, this legislation is in the making, thus the results will be known in the future.

\section{CONCLUSIONS}

This paper presented the origin and transformation of $\mathrm{PMH}$, which are unique rural landscape elements of the Krotoszyn environs. With respect to the ecological and cultural aspects, PMH constitute a challenge for future landscape protection; nevertheless, as was stated before, the preservation of these wilderness marginal elements as an aspect of landscape diversity in a highly human-operated area is not an easy task.

The results indicate how the farmers' attitudes towards their place of living can strongly determine both the direction and intensity of landscape transformation. Generally, farmers focus on increasing farming production; however, providing education to better understanding the local environment in order to manage the landscape in the future is recommended in order to improve individual knowledge about the value of the place of living. 


\section{REFERENCES}

ANTON, C.E., \& LAWRENCE, C. (2014). Home Is Where the Heart Is: The Effect of Place of Residence on Place Attachment and Community Participation. Journal of Environmental Psychology, 40, 451-461.

BARTKOWSKI, T. (1949). Z obserwacji nad „oczkami” Równiny Koźmińskiej [From Observation Over the 'Eyes' of the Koźmińska Plain]. Sprawozdanie PTPN, 2(16), 17-20.

BEHM, H. (1993). Die historische Komponente der standortkundlish - landeskulturellen Gebietsuntersuchung - dargestellt am Raum Kavelstorf (Warnowgebiet). Ph.D. thesis, Universität Rostock.

De GROOT, R. (2006). Function-Analysis and Valuation as a Tool to Assess Land Use Conflicts in Planning for Sustainable, Multi-Functional Landscapes. Landscape and Urban Planning, 75, 175-186.

DEMBIŃSKI, F. (1954). Osiągnięcia naukowe ośrodka poznańskiego w dziejach produkcji roślinnej [Scientific Achievements of the Poznań Unit in the History of Plant Production]. Przeglqd Zachodni, 10(1), 56-67.

FORMAN, R.T.T., \& GORDON, M. (1986). Landscape Ecology. New York: John Wiley \& Sons.

GEINITZ, F.E. (1920). Das Diluvium Deutschlands. Stuttgart: Schweizerbarth.

GRIPP, K. (1924). Über die äußere Grenze der letzten Vereisung in Nordwest-Deutschland. Mitt. geogr. Ges. Hamburg, 36, 160-245.

MARCUCCI, D.J. (2000). Landscape History as a Planning Tool. Landscape and Urban Planning, 49(3-4), 67-81.

MARKUSZEWSKA, I. (2006). Wpływ zagłębień pomarglowych na kształtowanie krajobrazu rolniczego wybranych fragmentów Wysoczyzny Kaliskiej w ostatnim stuleciu [The Impact of Post-Marl Hollows on Shaping the Rural Landscape in Selected Areas of the Kaliska Plateau During the Past Century]. Bogucki Wydawnictwo Naukowe. Poznań, 136.

MARKUSZEWSKA, I. (2013). Changes of Agricultural Landscape Pattern - Non-Natural Driving Forces Analysing Based on the North-Western Region of Poland. Quaestiones Geographicae, 32(1), 5-14.

NIEGODZISZ, J. (1993). Ocena przydatności niektórych surowców ilastych do rekultywacji gleb i ochrony jezior [Evaluation of the Usefulness of Some Clay Raw Materials for Soil Remediation and Lake Protection]. Zeszyty Postępów Problemów Nauk Rolniczych, 409, 27-35.

PINTO-CORREIA, T. (2008). Analysing the Landscape and the Structuring Role of Riparian Corridors. In: ARIZPE, D., MENDES, A., \& RABACA, J.E. (eds.), Sustainable Riparian Zones. A Management Guide (pp. 122-126). València: Gráfiques Vimar.

STANKOWSKI, W. (2012). Transformation from Natural (Thermal Contraction) to Anthropogenic (Resource Exploitation) Depressions in the Krotoszyn-Koźmin-Raszków Area (Polish Lowland). Geologos, 18(1), 43-50.

SZOSZKIEWICZ, J. (2000). Rolnictwo wielkopolskie w gospodarce regionu i ochronie środowiska [Wielkopolskie Farming in Regional Economic and Environmental Protection]. Wydawnictwo Akademii Rolniczej, Poznań.

Ustawa z 16 kwietnia 2004 r. o ochronie przyrody. Dz.U. z 2016, poz. 422 [Act on Nature Protection].

Ustawa z dnia 5 sierpnia 2015 r. o kształtowaniu ustroju rolnego. Dz.U. poz. 1433 i 2179 [Act on Shaping the Agricultural System].

Van DIJK, T. (2007). Complications for Traditional Land Consolidation in Central Europe. Geoforum, 38(3), 505-511.

VOS, W., \& MEEKES, H. (1999). Trends in European Cultural Landscape Development: Perspectives for a Sustainable Future. Landscape and Urban Planning, 46(1-3), 3-14. 
Landscape Pattern versus Farming Development. The Case of the Post-Marl Hollows (PMH) Landscape

WALKER, A.J., \& RYAN, R.L. (2008). Place Attachment and Landscape Preservation in Rural New England: A Maine Case Study. Landscape and Urban Planning, 86(2), 141-152.

WHEELER, R. (2014). Mining Memories in a Rural Community: Landscape, Temporality and Place Identity. Journal of Rural Studies, 36, 22-32.

WOLDSTEADT, P. (1929). Das Eiszeitalter Grundlinien einer Geologie das Diluviums. Stuttgart: Enke.

ZIMMERBAUER, K., \& PAASI, A. (2013). When Old and New Regionalism Collide: Deinstitutionalization of Regions and Resistance Identity in Municipality Amalgamations. Journal of Rural Studies, 30, 31-40. 